\title{
IDENTIFICATION OF TWO ENTOMOPATHOGENIC FUNGI NATURALLY INFECTING PTEROCHLOROIDES PERSICAE (CHOLODKOVSKY 1899) (HEMIPTERA, APHIDIDAE) IN PEACH ORCHARDS IN TUNISIA
}

\author{
LASSAAD MDELLEL*, JOUDA GUESMI, \\ and MONIA BEN HALIMA KAMEL
}

High Institute of Agronomy of Chott-Mariem, University of Sousse, 4042, Tunisia

* Corresponding author: mdellell_tn@yahoo.fr

\begin{abstract}
Symptoms of mycosis of Pterochloroides persicae (Cholodkovsky 1899) (Hemiptera, Aphididae) in a peach and almond orchard were recorded in April 2011. The causal agent was morphologically identified. Polymerase chain reaction (PCR) of the internal transcribed spacer region (ITS1 and ITS4) was used for molecular identification and verification of the morphological determination. Both methods gave consistent results and we recorded for the first time the natural occurrence of two fungal species belonging to the order Hypocreales (Phylum Asocomycota); Beauveria bassiana Viull (Hypocreales, Cordycipitacae) and Metacordyceps liangshanensis (Hypocreales, Clavicipitaceae).
\end{abstract}

Keywords: Beauveria bassiana, Metacordyceps liangshanensis, Pterochloroides persicae, Tunisia

\section{Introduction}

The giant brown peach aphid Pterochloroides periscae (Cholodkovsky 1899) (Hemiptera, Aphididae) is a worldwide pest of peach, almond, plum, apricot, apple and citrus (Stoetzel and Miller 1998; Ateyyat and Abu-Darwish 2009; Mdellel et al. 2011). It occurs in Europe, Asia, North America and some Mediterranean countries (Kairo and Poswal 1995; Blackman and Eastop 2000). In Tunisia, it was first recorded in 1987 at Sfax (Southern of Tunisia) on almond trees (El-Trigui and El-Shérif 1989) and is considered to be a serious pest of stone fruit trees, especially peach, almond, plum and apricot (Ben Halima-Kamel and Ben Hamouda 2004, 2005; Mdellel et al. 2011). This aphid causes severe damage to its host plants at all growth stages and often kills trees (Kairo and Poswal 1995). In order to control this pest, many of its natural enemies have been identified and used as biological control agents, of which Pauesia antennata Mujerji (specific parasitoid of $P$. persicae) and Coccinella algerica Kovar are considered to be the most important (Rakshani et al. 2005, Mdellel et al. 2012). Similarly, other natural's enemies can be so used, such as the entomopathogenic fungi. Indeed, fungal diseases of insects are common and widespread and many of them are considered to be important factor regulating pest insect populations (Carruthers and Soper 1987).

Entomopathogenic fungi are recorded as important causes of aphid mortality all over the world (Latge and Papierok 1988). Currently, at least 90 genera and more than 700 species of entomopathogenic fungi infecting invertebrates have been identified, most of which are associated with insects, but only 100 of these have been or are currently being developed for insect control (Wraight et al. 2001). Intensive studies have increased our understanding of the distribution and epidemiology of fungi in insect populations and their use as biological control agents of pests of agricultural crops (Pell et al. 2001). In fact, in temperate regions, Hyphomycetes are important fungal pathogens of aphids (Barta and Cagan 2006). Thus sampling of host individuals can reveal information about the prevalence of fungal species as pathogens in natural host population. The use of entomopathogenic fungi in biological control is a new field in Tunisia. The objective of the present study is to identify isolates of entomopathogenic fungi from P. persicae cadavers naturally infected with fungi.

\section{Materials and Methods}

\section{Sampling}

This investigation of mycoses in $P$. persicae populations was done in three regions of Tunisia, in the north: at Ariana (SidiThabet: $36^{\circ} 54^{\prime} 31^{\prime \prime} \mathrm{N}, 10^{\circ} 02^{\prime} 33^{\prime \prime} \mathrm{E}$ ) an arid area and at two regions on the coast of Tunisia: the first at the High Agronomic Institute at Chott Mariem $\left(35^{\circ} 52^{\prime} 31^{\prime \prime} \mathrm{N}, 10^{\circ} 34^{\prime} 16^{\prime \prime} \mathrm{E}\right)$ and second at Jammel $\left(35^{\circ} 38^{\prime} 24^{\prime \prime} \mathrm{N}, 10^{\circ} 45^{\prime} 36^{\prime \prime} \mathrm{E}\right)$. The last two regions have an arid climate. Aphid cadavers showing symptoms of infection with fungi (Figs. 1 and 2) were placed in ventilated plastic boxes and carried to the laboratory.

\section{Fungal Identification}

Fungal cultures were obtained from aphid cadavers by isolating them on potato dextrose agar (PDA) af- 


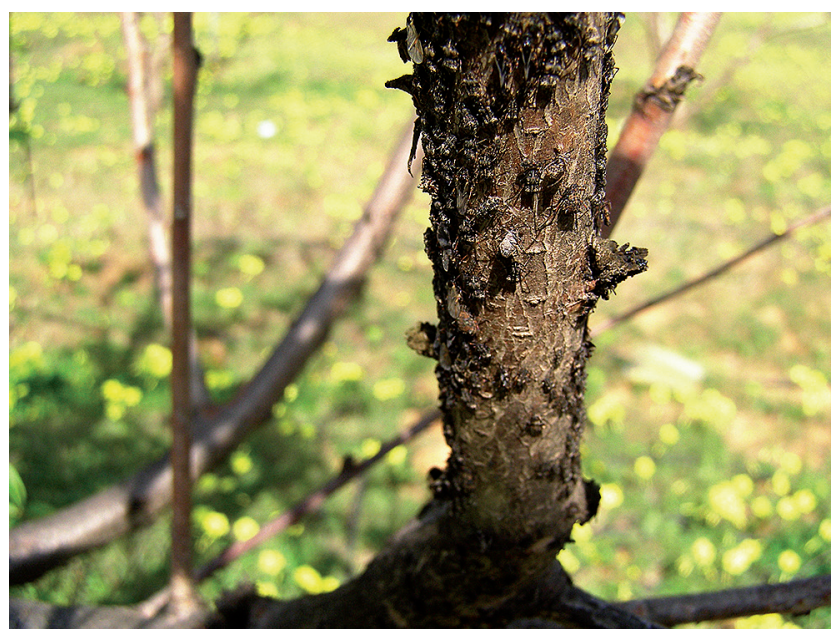

Fig.1 Pterochloroides persicae population on peach showing symptoms of infection with entomopathogenic fungi.

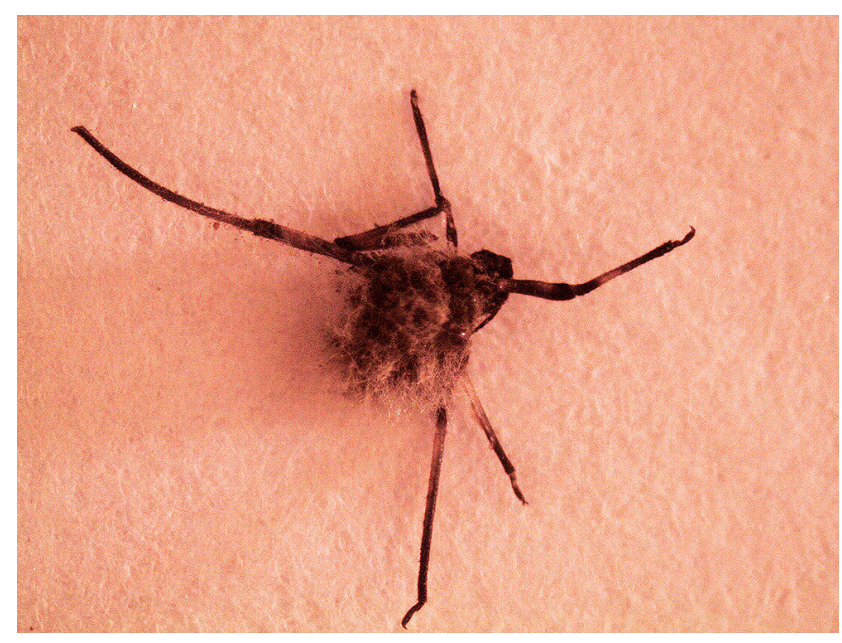

Fig. 2 Pterochloroides persicae cadaver showing symptoms of having been killed by a fungal infection. ter surface-sterilization following the procedures used by Goettel et al. (2000). Microscopic descriptions were made using cultures on PDA and MA (Malt agar). Mycelia were mounted in lacto phenol cotton blue $(0.01 \%)$ and observed under phase contrast using a Leitz DMRB optical microscope $(40 \times / 0.65$ PH2 and $100 \times / 1.25$ OIL PH3). Fungal preparations were photographed using a Coolpix 5000 5.0 MP digital camera. The fungi were identified (based on morphological characteristics) under a stereoscopic microscope (Nikon SMZ 800 with light source Intralux 4000-1) with the aid of the taxonomic keys of Lawrence (1997), Humber (1997) and Barnett and Hunter (2006).

Genomic DNA extraction from mycelia was done using the method described by Reader and Broda (1985). DNA was amplified by PCR using the complementary primers ITS1F and ITS4 and a MyCycler TM thermocycler System (Bio-Rad, Madrid, Spain) according to the manufacturer's instructions (Promega, Madison, WI, USA). The sequences were compared with those available in the GenBank database using BLAST search analysis (sequences were initially aligned using DNASTAR Inc. (Madison, WI, USA).

\section{Results and Discussion}

Two entomopathogenicfungi naturally infecting P. persicae were identified: Beauveria bassiana (Balsamo) Vuillemin (Ascomycota: Hypocreales, Cordycipitaceae) and Metacordyceps liangshanensis (Ascomycota: Hypocreales, Clavicipitaceae). These two species are reported for the first time infecting $P$. persicae. Nevertheless, Tsinovskii and Egina (1972), cited by Cross and Poswal (1996), report Entomophthora thaxteriana Petch infecting P. persicae, which is now named Conidiobolis obscuris, and is the cause of substantial mortality in several species of aphids.
In addition, in Israel, Ben Zev (1988) report another species of entomopathogen attacking this aphid called: Taxterosporium tubinatum Kenneth.

Several studies have demonstrated that B. bassiana infects hundreds of species of hosts belonging to many insect orders (Nicolai et al. 2006). Gurulingappa et al. (2011) demonstrate the efficiency of this fungus against Aphis gossypii Glover. These authors report that it reduces the longevity and fecundity of aphids, and is thus potentially an excellent biological control agent. Similarly, Sevim et al. (2012) note that much effort has been put into research on the development of B. bassiana as a biological control agent (for inundative and inoculative biological control) for use in agriculture and forestry in temperate regions. In South Korea, Kim et al. (2013) have demonstrated also that spraying green peach aphids with a filtrate of cultures of $B$. bassiana results in a high mortality (78\%) of the aphid three days after the treatment. Akmal et al. (2013) tested the efficiency of B. bassiana against several species of aphids (Schizaphis graminum (Rondani 1852), Rhopalosiphum padi (L., 1758), Brevicoryne brassicae (L., 1758) and Lipaphis erysimi (Kaltenbach 1843) in the field and showed it can be used as a biocontrol agent for managing these aphids. M. liangshanensis, Kepler et al. (2013) infects species of Lepidoptera in USA. Currently, the relative virulence of infections by B. bassiana and M. liangshanensis in P. persicae is unknown, but future pathogenicity assays will clarify whether they are both highly virulent biological control agents of $P$. persicae.

In conclusion, the present study provides the first report of $B$. bassiana and $M$. liangshanensis infecting $P$. persicae populations infesting peach and almond trees in Tunisia, but further research is needed on the relative efficiency of these two entomopathogenic fungi against $P$. persicae and their potential as biological control agents. 


\section{Acknowledgements}

We are grateful to Sandra Ma Castuera Santacruz and Carlos Campos Porcuna (ETSIAM, University of Cordoba, Spain) for excellent technical assistance in the laboratory and to Ms Bchir Amani for comments on earlier versions of this manuscript. This research was supported by project AGR-7681 from the Consejería de Innovación, Ciencia y Empresa de la Junta de Andalucía.

\section{REFERENCES}

Ateyyat MA, Abu-Darwish MS (2009) Insecticidal activity of different extracts of Rhamnus dispermus (Rhamnaceae) against peach trunk aphid Pterochloroides persicae (Homoptera: Lachnidae). Span J Agric Res 7: 160-164.

Akmal M, Freed S, Malik MN, Gul HT (2013) Efficacy of Beauveria bassiana (Deuteomycotina, Hypomycetes) against different aphid's species under laboratory conditions. Pak J Zool 45: 71-78.

Barnett HL, Hunter BB (1998) Illustrated genera of imperfect fungi, St. Paul, American Phytopathological Society Press.

Barta M, Cogan L (2005) Recordes of aphidophagous Entomophthorales in Slovakia. Insect pathogen and Insect parasitic Nematodes. IOBC, WPRS Bulletin 28: 69-72.

Ben Halima K M, Ben Hamouda M H (2004). Aphids of fruits trees in Tunisia In: Simon JC, Dedryver CA, Rispe C, Hullé M (eds) Aphids in a New Millennium. Procceeding of the VIth International Symposium on Aphids. INRA Editions: 119-123.

Ben Halima Kamel M, Ben Hamouda MH (2005) A propos des arbres fruitiers de Tunisie. Notes fauniques de Gembloux 58: $11-16$

Ben-Ze'ev IS, Zelig Y, Briton S, Kenneth RG (1988) The Entomophthorales of Israel and Their Arthropod Hosts: Additions 1980-1988. Phytoparasitica 16: 247-257.

Blackman RL, Eastop VF (2000) Aphids on the world's trees: an identification and information guide. CABI, Wallingford, UK.

Carruthers RI, Soper RS (1987) Fungal diseases. In: Fuxa JR, Tanada Y (eds) Epizootiology of insect diseases. John Wiley and Sons, New York, pp. 357-416.

Cross AE, Poswal MA (1996). Dossier on Pauesia antennata Mukerji. Biological Control Agent for the Brown Paech Aphid, Pterochloroides persicae in Yemen. IIBC.

El Trigui AW, El Sherif R (1989) A survey of the important insects, diseases and others pests affecting almond tree in Tunisia. Arab J Pl Prot 5: 1-7.

Gurulingappa P, McGee PA, Sword G (2011) Endophytic Lecanicillium lecanii and Beauveria bassiana reduce the survival and fecundity of Aphis gossypii following contact with conidia and secondary metabolites. Crop Prot 30: 349-353.

Goettel MS, Inglis GD, Wraight SP (2000) Fungi. In: Lacey LA, Kaya HK (eds) Field manual of techniques in invertebrate pathology, application and 193 evaluation of pathogens for control of insects and other invertebrate pests. Kluwer 194. Academic Publishers. Dordrecht, the Netherlands.
Humber RA (1997) Fungi-Identification. In: Lacey L (ed) Manual of Techniques in Insect Pathology. London, Academic Press, pp. 153-185.

Kairo MTK, Poswal MA (1995) The brown peach aphid Pterochloroides persicae (Lachninae, Aphididae): Prospects for IPM with particular emphasis on classical biological control. Biocontrol News Inform 16: 41-47.

Kepler R, Ban S, Nakagiri A, Bischoff J, Hywel-Jones N, Owensby CA, Spatafora JW (2013) The phylogenic placement of hypocrealean insect pathogens in the genus Polycephalomyces: an application of one name. Fung Biol 117: 611-622.

Kim JJ, Gayoung J, Han JH, Lee SY (2013) Biological Control Aphids Using Fungal Culture and Culture filtrates of Beauveria bassiana. Microbiol 41: 221-224.

Lawrence LA (1997) Manual of Techniques in Insect Pathology. Academic Press, London.

Latge JP, Papierok B (1988) Aphid's pathogens. In: Minks AK, Harrowing P (eds) Aphids. Their Biology, natural's enemies and control 2B. Elsevier, pp. 323-335.

Mdellel L, Ben Halima KM, Teixeira Da Silva JA (2011) Effect of Host Plant and Temperature on Biology and Population Growth of Pterochloroides persicae (Cholodkovsky) (Hemiptera, Lachninae). Pest Tech 5: 74-78.

Mdellel L, Ben Halima KM (2012) Prey conception efficiency and fecundity of the ladybird beetle, Coccinella algerica Kovar (Coleoptera, Coccinellidae) feeding on the giant Brown bark aphid, Pterochloroides persicae (Cholodkovsky) (Hemiptera: Lachninae). Afr Entomol 20: 292-299.

Nicolai VM, Jorgen E (2006) Isolation and characterisation of Beauveria bassiana isolates from phylloplanes of hedgerow vegetation. Mycol Res 110: 188-195.

Pell JK, Eilenberg J, Hajek AE, Seinkraus DC (2001) Biology, Ecology and Pest management potential of Entomophthorales. In: Butt TM, Jackson C, Magan N (eds) Fungi as Biocontrol Agents: Biocontrol Agents: Progress, Problems and Potential. CAB, International, pp. 71-153.

Reader RU, Broda P (1985) Rapid preparation of DNA from filamentous fungi. App Microbiol 1: 17-20.

Rakhshani E, Talebi AA, Stary P, Manzari S, Rezwani A (2005) Re-description and Biocontrol Information of Pauesia antennata (Mukerji) (Hym., Brachonidae) Parasitoid of Pterochloroides persicae (Chol) (Hom., Aphidoidea, Lachnidae). J Entomol Res Soc 7: 59-69.

Sevim A, Hofte M, Demirbay Z (2012) Genetic variability of Beauveria bassiana and Metarhizium anisopliae var. anisopliae isolates obtained from the Eastern Black Sea Region of Turkey. Turk J Biol 361: 255-265.

Stoetzel MBS, Miller G (1998) Aphids (Homoptera: Aphididae) colonizing peach in the United States or with potential for introduction. Fla Entomol 81: 325-345.

Tsinovskii YP, Egina KY (1972) The use of Entomophthora fungi in the control of aphids. In: Tsinovskii YP (ed) The pathology of insects and mites. Riga, Latvian SSR; Izdatel'stvo Zinate.

Wraight SP, Jackson MA, De Kock SL (2001) Production, stabilization and formulation of fungal biological agents. In: Butt TM, Jackson C, Magan N (eds) Fungi as Biocontrol Agents, CABI, Wallingford. 